\title{
Painful Neutrality: Screening the Extradition of the Balts from Sweden
}

$\$$ sciendo

LARS KRISTENSEN, University of Skövde, Sweden; email: lars. kristensen@his.se CHRISTO BURMAN, Linneaus University, Sweden; email: christo.burman@Inu.se 


\section{ABSTRACT}

The article deals with the extradition of Baltic soldiers from Sweden in 1946 as represented in Per Olov Enquist's novel The Legionnaires: A Documentary Novel (Legionärerna. En roman om baltutlömningen, 1968) and Johan Bergenstråhle's film A Baltic Tragedy (Baltutlämningen. En film om ett politiskt beslut Sverige 1945, Sweden, 1970). The theoretical framework is taken from trauma studies and its equivalent within film studies, where trauma is seen as a repeated occurrence of a past event. In this regard, literature and moving images become the means of reaching the traumatic event, a way to relive it. What separates the extradition of the Baltic soldiers from other traumas, such as the Holocaust, is that it functions as a guilt complex related to the failure to prevent the tragedy, which is connected to Sweden's position of neutrality during World War II and the appeasement of all the warring nations. It is argued that this is a collective trauma created by Enquist's novel, which blew it into national proportions. However, Bergenstråhle's film changes the focus of the trauma by downplaying the bad conscience of the Swedes. In this way, the film aims to create new witnesses to the extradition affair. The analysis looks at the reception of both the novel and film in order to explain the two different approaches to the historical event, as well as the two different time periods in which they were produced. The authors argue that the two years that separate the appearance of the novel and the film explain the swing undergone by the political mood of the late 1960s towards a deflated revolution of the early 1970s, when the film arrived on screens nationwide. However, in terms of creating witnesses to the traumatic event, the book and film manage to stir public opinion to the extent that the trauma changes from being slowly effacing to being collectively 'experienced' through remembrance. The paradox is that, while the novel still functions as a vivid reminder of the painful aftermath caused by Swedish neutrality during World War II, the 


\section{film is almost completely forgotten today. The film's mode of attacking the viewers with an I-witness account, the juxtaposition and misconduct led to a rejection of the narrative by Swedish audiences.}

In January 1946, 146 soldiers from the Baltic countries boarded the Soviet ship Beloostrov at the Swedish harbour of Trelleborg. They were Baltic soldiers wearing German uniforms, who had fled their native countries in the spring of 1945 as the Red Army advanced into Europe. While thousands of civilian refugees from the Baltic region were granted refugee status and eventually Swedish citizenship, the soldiers in Trelleborg were sent back to the now Soviet Union as part of the peace agreement between the major warring nations. Neutral Sweden had agreed to return German Wehrmacht soldiers, but the request from the Soviet authorities to extradite the Baltic soldiers to the Soviet Union was tentative. Could a distinction be made between the victorious nations? Was the Soviet Union a peaceful and just nation or a brutal and unscrupulous dictatorship? It was by no means a straightforward matter, and the fact that the Swedish authorities could not guarantee the safety of the soldiers once they were back in their Soviet-controlled countries made the matter take on epic proportions. The soldiers themselves were certain that they would face court martials and possible executions, which led them to organise a collective hunger strike in protest against the extradition. A few even took their own lives while still in Sweden.

The extradition of the Baltic soldiers from Sweden after World War II became a hot topic in the late 1960s and again in the early 1970s due, initially, to the release of Per Olov Enquist's The Legionnaires: A Documentary Novel (Legionärerna. En roman om baltutlämningen, 1968), and later Johan Bergenstråhle's film A Baltic Tragedy
(Baltutlämningen. En film om ett politiskt beslut Sverige 1945, Sweden, 1970). International literature on the Baltic question makes no mention of the event (e.g. Hiden et al. 2008), and the debates related to the extradition have largely been confined to Sweden. This article seeks to fill this gap in the academic literature by providing an account of how this debate unfolded. We contend that the two accounts of the events - Enquist's book and Bergenstråhle's film - had quite different receptions, and that the reason was not only the different focuses of the two accounts, which reflect a deep split between the two different media depicting the historical events, but also the time that lapsed between the release of the book and the premiere of the film. We argue that while Enquist's documentary novel was well received by readers and critics and is still promoted and read today, ${ }^{1}$ Bergenstråhle's film has mostly been forgotten and its images obliterated from the Swedish consciousness. We will show that both the novel and film were influenced by left-wing politics and in particular Marxist ideas about accounting for historical events, i.e. that the present is an experience of what once was or what no longer exists (Mazierska 2014: 253). However, the two productions were eclipsed by the dramatic events of 1968, which saw a Marxist uprising in the West, also known as May 1968, and the end of the Prague Spring caused by

\footnotetext{
The book was re-released in 2018 by the publisher Norstedt as part of the novel's 50th anniversary. In the new preface entitled 'A Swedish Trauma' ('Ett svenskt trauma'), by the Norwegian reporter and author Åsne Seierstad, she argues that Enquist's novel is a testimony against the rise of 'alternative facts', 'fake news' and 'individual truths' (Seierstad 2018: 10).
} 
Soviet military intervention in the East only a few months later. We argue that Enquist wrote his book in the spirit leading up to May 1968, while Bergenstråhle's film suffered the consequences of the failures of May 1968, which culminated with Here and Elsewhere (Ici et ailleurs, Jean-Luc Godard, Jean-Pierre Gorin, Anne-Marie Miéville, France, 1976), a failed revolutionary film project, which signalled the end of an era. In French academia during the mid-1970s, even 'a reference to Marx became a mark of ignominy' (Matheron 1997: 9). By the time A Baltic Tragedy was broadcast on Swedish television in January 1978, the political winds had turned completely from the time when Enquist started his investigation over a decade earlier.

The argument will be structured as follows. In the first part of the essay, we will deal with Enquist's book and its reception. Here we show that a genuine discussion about the representation in the book only occurred after the voices of the Baltic diaspora in Sweden entered the public debate. In the second part, we will look at the production, exhibition and reception of the film in cinemas, as well as the discussion of the event as it unfolds on national television. In this account, we will provide a combination of textual and reception analysis, together with a discussion of how the aftermath of the film was influenced by politicians, critics and the members of the film crew who were not at all happy with the result. The final section will focus on the screening of the film on television, which reignited something that was, by that time in the late 1970s, a national war trauma. Before returning to Enquist's historical novel, we first need to address the concept of trauma in cinema.

\section{TRAUMA STUDIES AND FILM}

Trauma studies is a separate discipline, associated mainly with Holocaust studies, but the origins of which lie in the writings of Sigmund Freud. It is the research into the psychological consequences of violent events - such as war, political torture or other tragedies of massive human loss - for which trauma studies seeks to develop a treatment along the lines of clinical psychology. Trauma studies have also been conceptually adopted by other fields in the humanities, of which literature and film studies are the best-known. In the literary branch of trauma studies, the focus is on an 'afterwardness' that can be both realistic and artistic in its representation, but which coalesces different time periods into the present. According to Robert Eaglestone, trauma studies is about the 'structure of experience' (Eaglestone 2014: 17). The Holocaust and the study of the remembrance of the Holocaust dominate this branch of study, to which we can add Enquist's and Bergenstråhle's creative endeavours. However, as already mentioned, there are differences between their work, and it can be asserted that Enquist is the starter culture, and Bergenstråhle the follower. We suggest that Enquist's book created public awareness about the event's traumatic proportions, and in a sense, it can be considered to be the creator of the trauma. Bergenstråhle's film, however, is aimed at creating new witnesses to this newly established trauma and to giving it national proportions.

Drawing on the works of the feminist trauma researcher Elizabeth Waites, Janet Walker argues that trauma 'impoverishes fantasy life by generating an endless repetition of flashbacks that almost mechanically reproduce the remembered trauma, and it contributes to fantasy life by helping to generate structures that depart from literal transcriptions of the past events' (Walker 2005: 10). The repeated nature of trauma is echoed by Ann E. Kaplan and Ban Wang (2004: 5) in their introduction to Trauma and Cinema, in which the traumatic event "takes the form of repeated, intrusive hallucinations, dreams, thoughts or behavior' (Kaplan, Wang 2004: 5). We argue that Enquist established a Swedish war trauma that was not self-evident in the social imagination before his novel. The event was seen as a controversial political decision, but not as a traumatic one. Enquist, in contrast, elevates this historical event to the level of trauma and thereby creates an 
'impoverished' imagination about the extradition of the Baltic soldiers.

The fact that the trauma is regenerated and reproduced repeatedly, forming a Freudian link of trauma to fantasy and fiction, is vital in this regard. Trauma "provides a way of connecting the unconscious and history' (Kaplan 2001: 202). Departing from factual writing about past events is part and parcel of creating trauma. While, for the most part, the literature on trauma deals with victims of violence or mass persecution, it is important to emphasise that Enquist's creation of a Swedish war trauma is narrated from the perspective of the perpetrators. In some sense it is about a lack, or an emptiness, that the author seeks to address (Thurah 2002: 34). There is something wrong before the novel begins, and this emptiness can be filled with a trauma (Thurah 2002: 19). Thus, it is about not acting or saving lives, e.g. sending Jewish refugees back to Nazi Germany or Baltic soldiers back to the Soviet Union. Above all, it is about the problem of claiming neutrality as a moral high ground, which is effectually equated with being on the same side as the perpetrators. Traumatic memory works to Enquist's advantage because 'traumatic memory is distinguished from other evidentiary forms precisely because it eludes the binaristic "it happened or it didn't"' (Walker 2001: 212). What actually happened is not as significant as establishing a social imagination, or 'fantasy life', that repeats the event over and over again.

Moving to the visual representation of the traumatic event and Bergenstrăhle's film, we are introduced to the I-witness, who provides an account of the atrocities. According to Shoshana Felman and Dori Laub's work on Holocaust witnesses, 'media technology became the means by which survivors recovered their traumatic experiences, possibly for the first time' (Ashuri 2010: 174). If an I-witness narrative is seen as dealing with a traumatic event, which by no means necessitates a truthful or accurate storytelling (Walker 2001:

216), then screening such narratives also helps create new witnesses, who are ethically bound up in the atrocities (Torchin 2012). Thus, we also move into the notion of creating witnesses, i.e. that watching moving images, even if they are reconstructed, extends responsibility onto the viewer. Leshu Torchin is one of the main advocates of this concept, saying that

the capacity of film to do something to the spectator is a longstanding concern in film study [which] suggests that the encounter with the screen does something to the viewer - shaping him ideologically or provoking her into response. This notion of inevitable transformation carries into assumptions or demands around viewing distance suffering, where audiences are made responsible for what they have seen. (Torchin 2012: 11)

\section{It is Torchin's argument that since its} inception media technology has enabled a transfer of responsibility onto viewers. This ability is evident from the very early days of cinema. In regard to the genocide film Ravished Armenia (Oscar Apfel, USA, 1919), which screened the eyewitness testimony of Aurora Mardiganian, who also starred in the film, Torchin asserts that 'these new media enabled more immediate contact with suffering at a distance, presenting trauma for the viewers "at home"' (Torchin 2006: 215). The key concepts for Torchin include testimony and witness, because these 'oblige' the viewer to act through legal procedures, political actions or financial support of charities, as was the case with Ravished Armenia. Another approach to memory and moving images is mnemonic rationality, in which memory is seen 'as a relational process that encompasses biological, mental, social and material dimensions, thus creating changeable mnemonic assemblages' (Erll 2017: 7). We can argue that creating witnesses is a neurological process of mnemonic assemblage in which the emotions of trauma are felt although through the stories of others. While A Baltic 
Tragedy does carry a few l-witness accounts in terms of featuring the Baltic soldiers, it mainly strives toward historical accuracy by casting diaspora actors and the choice of its locations. Thus, it does aim to create witnesses through its screenings. It presents a war trauma for Swedish viewers, but what actions did the filmmaker expect from the spectators? This question sets the film apart from other witness films like Ravished Armenia, because A Baltic Tragedy does not have a clear purpose other than to produce a sense of guilt in the general population.

Based on the writing of Susan Sontag, Neil Narine points out that 'bearing witness readily induces guilt' (Narine 2010: 120) and this works in the case of Bergenstråhle's film. That said, screening A Baltic Tragedy for a Swedish audience is also about creating awareness of what happened in the aftermath of World War II in Sweden. This becomes evident, not when the film was shown in cinemas, which generally did not attract attention, but when it was broadcast on national television with accompanying debates and current affair programming about the film. The film was talked about on national television thereby creating the witnesses. It can be argued that a traumatic event of this scale creates a community and shared sense of national guilt (Mazierska 2011: 24) on a much larger scale than the book can. This is the second phase of our argument, i.e. once the film was actually broadcast on television in 1978, its aesthetic and political style of filmmaking was generally rejected by the audiences and the critics but, by then, the memory of the trauma had already become a fact.

Exploring the concept of post-memory, Ewa Mazierska finds that there are two views on how trauma, and in particular the Holocaust, can be represented (Mazierska 2011: 22-27). One view is that barbarity cannot be represented, since any representation would be incomplete and thus futile, a view that Theodor W. Adorno held with respect to the Holocaust. The other view is that any representation is better than no representation, which means that in order to remember atrocities they must be represented and discussed. However, the latter view also creates the burden of history, i.e. there is so much out there (in particular regarding the Holocaust) that it is impossible to comprehend all the available material. Mazierska writes that the burden of history 'might overwhelm a person who inherits the painful memories, either due to being personally connected with their owner or due to belonging to an (imagined) community connected by these memories' (Mazierska 2011: 26). Individual and collective memories are linked through trauma (Buelens et al. 2014: 2), which means that a shared sense of guilt can easily function as the linkage between individually experienced and collectively imagined trauma. We argue that the memory of the extradition of the Baltic soldiers is an imagined community memory that connects Swedes to a shared trauma event, which happened in the final stage of World War II. Enquist resuscitates this trauma with the aim of social critique of the role of Swedes during the war, but instead creates a collective sense of trauma, which can be connected to national awakening rather than critiquing. We argue that this can be observed in the discrepancies related to the reception of the book and the film, whereby the diaspora rejects the memory while the majority of the population accepts the trauma as valid.

\section{ENQUIST'S NONFICTION NOVEL}

Truman Capote claimed to have created the genre of the nonfiction novel with his book In Cold Blood (1966). His factual account of the brutal murder of a farm family in Holcomb, Kansas, was dramatised to fit the form of the novel. The anchor of the story is Truman Capote himself, and the work is semiautobiographical, delivered in the form of a witness narrative. In the history of literature, fact and fiction can be seen as the relationship between realism and romanticism, which in the absence of a divine authority, starts appearing in both fiction and nonfiction writings in the 18th century (Johansson 2008: 35). Capote was obviously not the first, but his term has 
been accepted in English literature studies, and today goes under the umbrella of creative nonfiction. Laura Tansley and Micaela Maftei explain:

Unclear boundaries between fact and fiction can be freeing, allowing authors to tell stories using structures, techniques and language of fiction, poetry and non-fiction, creating unique and personal testimony. In this way creative non-fiction can become a highly individual truth. Such testimony may be felt by the author to be truthful if not wholly factual. (Tansley, Maftei 2015: 5)

Thus, creative nonfiction is highly individual but emotionally affecting, regardless of whether it is factual or not. This is also Enquist's relationship with fact and fiction, which is expressed in the literature about trauma as being like a Freudian link between the unconscious and the factual event in history. The fact and fiction dichotomy can also be seen as a Deleuzian link between reality and thinking, which can exist without 'their immanent relationship' (Johansson 2008: 202). Neither is it a purely Western literary dichotomy, as Japanese literature has shōsetsu, which is a 'chronicle-novel', in which memories are 'somewhat embroidered and colored but essentially nonfiction all the same', as in Yasunari Kawabata's novel The Master of Go (名人) from 1951 (Seidensticker 1972: v). Based on Capote's example, whose book In Cold Blood was negatively reviewed by Enquist in 1966 (Enquist 1966), The Legionnaires is felt, or thought, to be truthful by the author, while at the same time not being wholly factual.

It was with this work, his sixth novel, that Enquist's career as a novelist truly began. Enquist has since published over 30 novels and plays, won numerous literary awards and been called one of Sweden's greatest living authors (Brown 2016). We will not deal with Enquist's other works, but hope that this short introduction will suffice to convey an image of a young writer and critic who had already proven his skills as a poet, essayist and novelist. The questions on which we are focusing are why and how Enquist selected this traumatic war event for literary examination. What were his reasons, and in which form did he choose to do so? After that, we will provide an account of the book's reception in order to establish whose trauma we are dealing with.

Enquist offers his reasons for writing it in the book itself. These include the neutrality of Sweden during the war and the position that Sweden took in the postwar period as a leading political economy in the world. Sweden experienced an economic boom during 'the record years', when modernisation, social reforms and a high standard of living became the norm. The boom was similar to the ones experienced in West Germany and Japan, but it was the Swedish model - built on a partnership between industry and the labour unions that stood out as the most advanced and forward-thinking. Sweden was progressive and, to some, even overconfident. It is in this attitude that we find the seeds of Enquist's inquiry into Sweden's role during the war years; in particular, the sense that Swedish politics had all the answers to the world's problems, i.e. if everyone was more like the Swedes, the world would be a better place to live in.

This attitude was not reserved for the labour market or the economy, but was also apparent in terms of social welfare, as well as gender and racial equality. In regard to the latter, the book starts with Enquist, called 'the investigator' in the book, attending a civil rights protest in Jackson, Mississippi. The investigator is hesitant and reluctant to participate - 'is their problem my problem?' he asks - which becomes synonymous with Sweden's role in World War II: '. ...he was there but did not participate. It felt fine' (Enquist [1968] 2018: 35; our trans(ation ${ }^{2}$ ). Especially the conditional that the nuance in Enquist's language, which we read into the sentence, was not rendered in the English version. 
follow-up sentence, 'it felt fine', is indicative of a moral superiority that comes from the role of neutrality. Enquist is later confronted for having this laissez-faire attitude toward world affairs by an American friend:

The world's conscience. I know, l've lived in Sweden. The Swedes have the world's only transportable conscience; they go around like professional moralists. They never speak of the situations when they themselves have been faced with moral conflicts. The troop transits, the extradition of the Balts. What do you know about the extradition of the Balts? (Enquist 1973: 31)

For Enquist, the extradition of the Balts becomes a trauma he was not aware of and therefore has to investigate. The trauma becomes a sort of dark energy that the writer was obsessed by; it becomes his duty and personal responsibility to report on it (Mazierska 2011: 26-27). However, since it is also linked to the Swedish national conscience, it is about unearthing an event that collectively resonates with national cohesion. In other words, it is a trauma that speaks to many rather than only a few. It is a national trauma rather than a trauma of the Baltic diaspora. In order to demonstrate this, we can point to the diaries of Zenta Maurina who fled to Sweden after the war and worked in Uppsala as a writer and scholar. Published in Swedish in the same year as Enquist's book, Maurina makes no mention of the extradition in her diaries, except in a passage about Hungarian refugees in 1956. Maurina writes,

the Hungarian refugees are met with greater care, humanity and friendliness than the refugees from 1945. Those who flee the Red Terror are no longer driven towards suicide as the only solution. They are received without demands for health certificates or other payments, thereby making peace [lugnar] with their bad conscience. (Maurina 1968: 192-193)

In our view, this shows that the extradition of the Balts was a historical event that popped up on certain occasions, but nothing that was spoken about or actively debated during the time leading up to 1968. In fact, when reading Maurina's diaries one is struck by the lack of awareness on the part Swedes regarding their Baltic neighbours. Maurina writes that Latvians might just as well come from the moon, that's how ignorant Swedes are about her country of birth (Maurina 1968: 151). Our point is that by the time Enquist starts his investigation, the extradition is about to fade from the memory of the population, which is evident from Osvalds Freivalds' The Tragedy of the Baltic Prisoners in Sweden 1945-1946 (De internerade balternas tragedi i Sverige år 1945-1946), which was also published in 1968. In the preface to Freivalds' book, which was entitled 'It is hard to remember - but necessary!', Bishop Sven Danell writes that 'for many Swedes, what happened is a constant aching abscess [böld]. It is a blow that cannot heal by itself. It must be opened' (Freivalds 1968: 5). It is not a wound yet, but we argue that it is what Enquist's book does to this 'aching abscess' that cannot be forgotten. Enquist's account breaks open the abscess and a national trauma erupts out of it. Suddenly, everybody is aware of the extradition and this leads to the 'public discussions' of the event (Ekholm 1984: 21). It is this creation of the national trauma that we want to examine in the reception of the book.

Most of the reviews of the book in the national press were positive. We did not detect any differences in the reception based on the political agendas of the newspapers, or between the tabloid and broadsheet press. According to the reviews, Enquist's book is about 'national guilt' (Liffner 1968), as well as about a political tragedy (Uisk 1968) that gradually 'glided' into being without any serious attention from the politicians behind it (Linder 1968). 
(Figure 1) The victims of the tragedy are those that believed the anti-Soviet propaganda and committed suicide in Sweden, but overall, Enquist is thought to be right in his analysis that extraditing the Baltic soldiers to the Soviet Union was the correct decision (Lagerlöf 1968). The timing of the reviews is also important, as the book was published just weeks after the Soviet invasion of Czechoslovakia, which crushed any notion of 'socialism with a human face'. Had it been released a couple of weeks before, the reception would likely had been different (Nilsson, Yrild 1972). In this light, Enquist's conclusions became a bit 'naïve' or even 'dead' in the contemporary climate (Lagerlöf 1968). The critical voices attacked the form of the investigation, arguing that it may be a brilliant novel, but it is bad history (Unger 1968), and that the form of the novel is what becomes real rather than reflecting reality (Lagercrantz 1968). It is about Swedish 'egocentric introversion', according to one reviewer (Sjöström 1969), which supports the view of the book as dealing with oneself rather than the Other.

It took about six months for the Baltic diaspora to enter the debate, and when they did, they claimed that Enquist's account of the events was misleading. Under the title 'A Baltic View on The Legionnaires', Harri Laks wrote that Enquist gives his readers sleeping pills to avoid facts; facts that would accurately explain the situation of the Baltic soldiers. For example, Enquist deals selectively with the events of first Russian occupation in the Baltic countries and says nothing about the deportations and NKVD's torture methods, which, according to Laks, renders Enquist's inquest into why the soldier takes his own life at Trelleborg harbour 'distasteful and false' (Laks 1969). For Laks, the answer is obvious - it was the fear of deportation and torture. Laks continues,

a Balt who reads The Legionnaires continues to have reflections extending far beyond the topic of the book. Or are they connected? [---] Certain heroic international
Swedish freedom fighters are able to see Fascism and Nazism in the Baltic people's urge to realise human rights in their home countries. (Laks 1969)

The irony is not lost on the Swedish reader here, as it is the same moral superiority or transportable conscience that Laks is attacking. This illustrates that the trauma that Enquist revives with his investigation is far from being about the victims of the tragedy or historical facts; rather, the book is about stirring a sense of national guilt.

Another war emigrant who seeks to refute Enquist's narrative is Arturs Landsmanis, who had worked in the Latvian Legion, but escaped to Sweden as a civilian. Landsmanis is very thorough in his dealing with Enquist's book, providing data and statistics that seek to add nuance to the event. The title of the pamphlet is The Misinterpreted Legionnaires: A Baltic Argument (De misstolkade legionärerna. Ett baltiskt debattinlägg), and it was published by the Latvian National Foundation, which since 1947 had worked for the restitution of an independent Latvia, and since 1991, has worked as a charity in Latvia. According to Landsmanis, Enquist's mistake is that he misrepresents the Baltic region and its people; their 'reality is different', argues Landsmanis (1970a: 9). In particular, it is the context of why the Baltic soldiers wore German uniforms that Landsmanis deals with. For Enquist, the soldiers are proto-fascists, but for Landsmanis they are national patriots seeking to restore the independence of their country. Thus, Landsmanis rejects Enquist's claim that 30 or 40 of the soldiers were guilty of war crimes (Landsmanis 1970a: 55). It is clear that Landsmanis' perspective is different from Enquist's, and that Landsmanis reads Enquist's account of the event as more of a documentary than fictional account. The two, Landsmanis and Enquist, argued over this matter on a few occasions and it would become apparent that the diaspora was divided on the matter (Enquist 1970a, 1970b; Landsmanis 1970b). Also obvious is the fact that in 


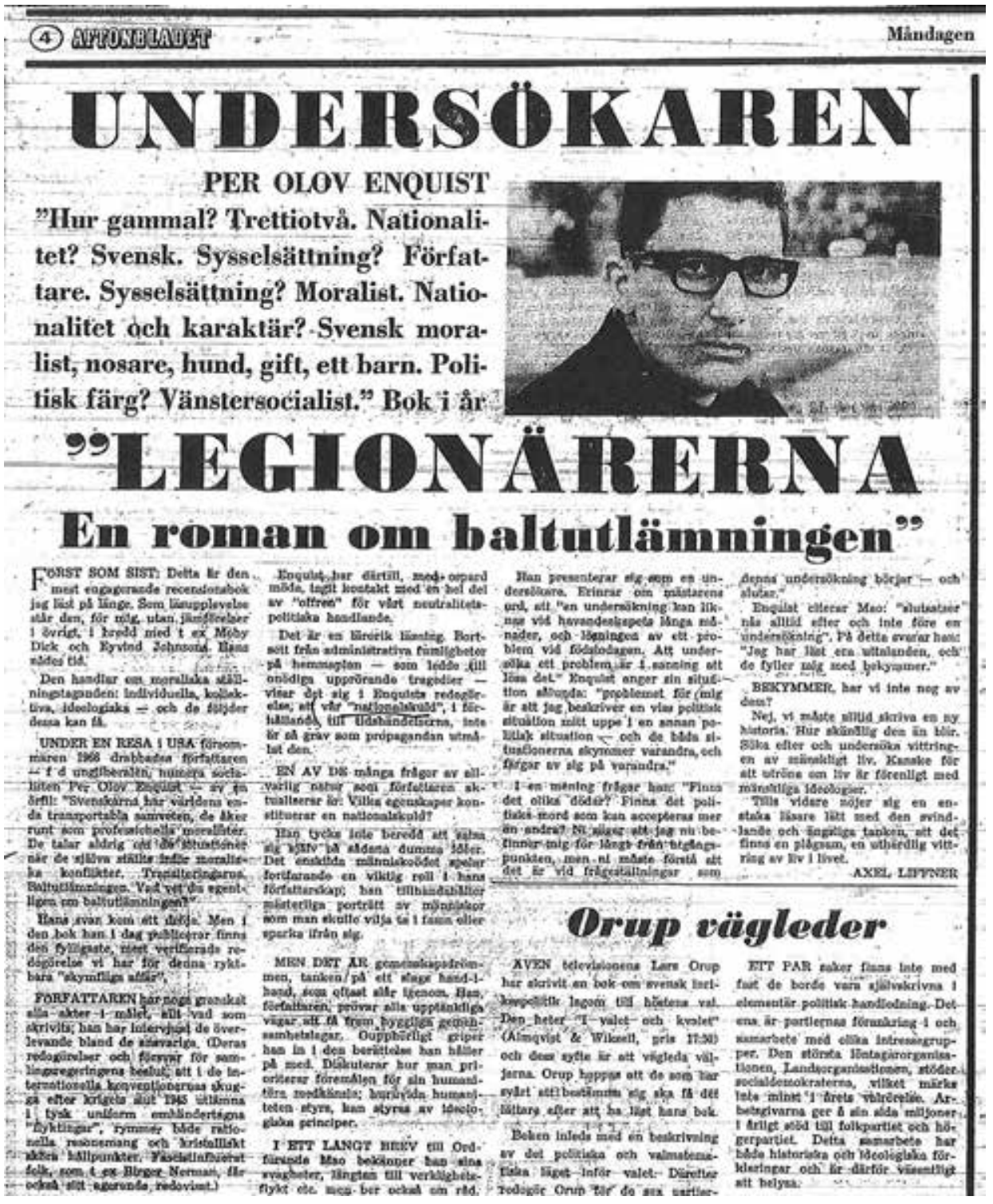

FIGURE 1. Liffner's review in Aftonbladet of Enquist's novel.

Scan of microfilm, Gothenburg University Library. 
Enquist's version the trauma is not about the victims of the event, i.e. the Baltic soldiers that suffered deportation, but 'the trauma of the Swedish guilty conscience'. This can also be seen in the form of the book, as alluded to in the reviews above.

When we discuss the novel in terms of its form, we also need to take a closer look at the political orientation of the author, and in Enquist's own words, his 'unbroken movement towards the political left' (Enquist 1973: 31-32). The period during which Enquist wrote the book is called 'the red 60s' by the Swedish historian, Kjell Östberg (2008: 339). For Östberg, 1965 is the demarcation line in the rise of Sweden's New Left, and it neatly frames Enquist's research and writing period (Östberg 2008: 341). Enquist associates himself with Marxism but disassociates himself from Soviet Communism: 'I am a socialist, but this is not linked to the Soviet Union', he says in an interview with the weekly journal Vår kyrka (Our Church) (Gustafsson 1968: 8). The Marxist approach to history is evident in his character description in The Legionnaires, where he amalgamates several people or historical facts into a single character. Margareta Zetterström (1970) points this out in her analysis of the book. In particular, this can be detected in the descriptions of the Swedish characters engaged in protesting the extradition, the people who are affected by the 'Swedish propaganda' ignited by the right-wing press and the diaspora community at the time. Enquist describes one of the protest meetings and a person named Eriksson, who is beaten up and loses a tooth, but Enquist has never met this person (Zetterström 1970: 525). The character is a synthesis of several persons amalgamated into one. This does not render the character inauthentic or false, but it is given dramaturgical purpose by the author. Enquist has created a person that stands for many, thus making it easier for most readers of the novel to identify with him. Of course, doing this to the Baltic soldiers and their plight upset those who had a vested interest in their description, like the Baltic diaspora as demonstrated above.
Another character that Zetterström deals with is a young Swedish woman who becomes involved with the protest movement when the soldiers go on a hunger strike in order to stall the extradition. This unnamed woman and her feelings toward the soldiers are elevated to national proportions. On the way home from a meeting, she cries. She is happy (lycklig) as she has experienced something strange, and for a brief moment, participated in something big. But when the soldiers are extradited she cries about something different. The sense of being involved has disappeared and this leaves her with an empty feeling (Zetterström 1970: 527). Zetterström connects this woman's feelings to Enquist's resignation during the demonstration in Jackson, Mississippi. But we can also see it as indicative of the general national mourning over an incurable trauma. The woman is not likely to have existed, but her feelings resonate with the Swedish audience, which takes us back to the objective of creative nonfiction and Truman Capote's term of the 'nonfiction novel'. In his review of In Cold Blood, Enquist is very critical of Capote's objectives. Conceding that Capote's book is about objectivity (saklighet), Enquist criticises it for being a romanticised objectivity, for popularising human suffering and aestheticising human degradation (Enquist 1966). At the end of the review, Enquist generalises the objective of an author of a nonfiction novel, stating that In Cold Blood is a failure, because 'one wants one's novel to affect one's opinion in a certain way, and give new insights into it' (Enquist 1966). Capote is reactionary, but Enquist wants to be a Marxist progressive without sugar coating his narratives; he wants to fill the empty space left by the passing of history. The conclusion that Enquist draws from Capote's book is 'hang the brutes', which is also the title of his review, indicating that Capote generates no sympathy in his readers for the main characters. Enquist, on the other hand, creates his characters out of a Marxist synthesis, where both truth and fiction are equal components. But this is how his Swedish characters are created, not the 
Baltic soldiers, whose one-dimensionality is a thorn in the side for the people in the diaspora.

The assertion that Enquist's novel targets the local (Swedish) audiences and therefore resonates well with Swedish readers is something that we will transfer to the account of the film. Although only two years elapsed between the publication of the book and the release of the film, the two were received very differently; we propose that one reason is that the film talks down to its audiences, trivialising the multi-dimensional Swedish characters of Enquist's book. The film, we argue, focuses more on the I-witness narrative of the Baltic soldiers than on the national sentiments of the local audiences.

\section{THE FILM: A BALTIC TRAGEDY}

There was significant attention surrounding the production of the film, including several newspaper reports from the shooting period during the autumn of 1969. One such report compares the scenes from the film to historical stills and also notes that Enquist wrote the screenplay together with Bergenstråhle (Stawonius 1969); another mentions the four potential layers of the film: reconstructions/re-enactments of historical events (shot in $35 \mathrm{~mm}$ colour); documentary material (shot in $16 \mathrm{~mm}$ black and white); interviews with politicians around 1945-1946; and, last but not least, a dialogue about these events at the time of the shooting (shot in $16 \mathrm{~mm}$ colour) (Edberg 1969). Bergenstråhle is quoted as emphasising these layers and their sources as a kind of morality and honesty (Edberg 1969). He says: 'I want to make it as documentary as possible, avoiding any kind of theatre. No known faces. Thus, for example, Swedish actors are excluded. I have mostly used amateurs, Balts for example' (Stawonius 1969). It is important to note that this was only a year after the publication of the book and the subsequent debate. Enquist was still promoting his book (Gustafsson 1969) as reports of the film's production appeared in the news. The historical event was thereby repeated over and over, which supports the fact that the historical event is now elevated to the status of a trauma, a source of guilt and pain that cannot be healed.

In the summer of 1970, Bergenstråhle's film was set to have its world premiere at the Berlin International Film Festival.

(Figure 2) However, the festival competition was cancelled due to disagreements among the jury and no prizes were awarded, due mainly to a controversy surrounding the participation of Michael Verhoeven's antiwar film o.k. (West Germany, 1970). The Swedish newspapers still reported on the film and the world premiere in Berlin, with Lasse Bergström claiming that the filmmakers' choice of a method that combines different kinds of material is
difficult to handle but Bergen- stråhle makes it work. Like Res- nais in Night and Fog, he achieves a sort of effect of coincidental levels of time by keeping the reconstruction in colour against the black-and-white journal images from 1945-1946, and he can constantly regulate the objectivity of the filmmaking with the grey and relentless truth in the documentary sequences. (Bergström 1970)

Furthermore, Bergström points out that the film 'is made in a condition and by a generation that is characterised by a kind of fear that differs from the fears of terror that were at the bottom of our Swedish reactions to the Baltic tragedy' (Bergström 1970). This comment is relevant because the documentary sequences support the fictional enactment. Although somewhat obvious, pointing to the historical differences between the most immediate post-war era and the late 1960s, the film enforced a contemporary reading as opposed to an understanding of an historical event. Hans Schiller, on the other hand, thinks that those who have not read the book are likely to 'get lost in this complicated mosaic' narration of history, and especially 'a foreign audience ... may have 
difficulties' deciphering the film (Schiller 1970a). The latter supports our claim that the trauma is limited to a collective national conscience. (Figure 3)

In Berlin, the film also encountered its first protests by the diaspora, as did the novel. Gunnar Pavuls, a native Latvian, who played a small role in the film, appeared at the film's press conference and posed a question regarding the problems of conducting interviews in Soviet-occupied Latvia (Cato 1970). This was a sensitive subject, as the producers at Svensk Filmindustri and Bergenstrăhle needed to get approval from the Soviet authorities to work in Riga - according to Pavuls this was a somewhat naively achieved success, since the Soviets would not allow any process that was not in their interest (Svedgård 1970). In other words, the film was not objective but compromised by Soviet collaboration. In the book, Enquist devoted an entire section to this methodological question, while the film does not mention it. This feeds into the fact that as early as August 1940, and as the only country in the world, Sweden granted de facto recognition to the annexation of the Baltic states by the Soviet Union. When the Swedish government accepted the handover of the Baltic delegations in Stockholm to the Soviet authorities, it meant that Sweden had accepted that the Baltic states had become Soviet Republics (Freivalds 1971: 7-13). ${ }^{3}$ From this point

Neither the United Kingdom nor the United States of America reacted in this way; in both countries, the individual diplomatic delegation of Estonia, Latvia and Lithuania continued, in accordance with UN resolutions, to act as representatives of their now occupied countries. Sweden acted differently, apparently to remain neutral (interpreting the annexation as voluntary and not as part of the war effort), but this decision casts a shadow over future decisions, such as the extradition of the Baltic soldiers, where Sweden acted as if it was locked into a position of de jure rather than de facto recognition of the Soviet occupation of the Baltic states. The status of the 1940 recognition of incorporation of the Baltic countries into the Soviet Union was debated continuously in the Swedish parliament (see Freivalds 1971: 9-11). In the early 1970s, when Olof Palme became a champion of the small nations and spoke out against the war in Vietnam, the question of the status of the Baltic states was raised. Does this concern include the fate of Estonia, Latvia and Lithuania? Andres Küng asks, but it is obvious that it does not (Küng 1970). The decision remained in place until the early 1990s and the collapse of the Soviet Union. onwards, the Soviets controlled Sweden's attitude toward the question of the status of the Baltic people and their countries. The film and book only enhanced this argument and acted as painful reminders of Sweden's neutrality during World War II.

The opening sequence of the film shows the structure of the work as a whole. We see a man (played by Yrjö Tähtelä, one of the few professional actors in the film) pulling a bed into the frame. Then he starts undressing. He goes to a cupboard and picks up a knife. Suddenly we hear a voice-over (by Bengt Ekerot) informing us that this man will soon be dead, and telling us the time, date and place of the incident. (Figure 4) The cause of death is suicide. The voice-over asks who is this man, then tells us his name, Oscars Lapa, and wonders whether deciding to extradite him was the right thing to do. The film then intercuts between Oscars Lapa and the Swedish politicians discussing the extradition of the Balts, until Lapa commits suicide. The opening illustrates how the narrative is constructed, focusing on the questions posed by the extradition, but chronologically ending at the harbour in Trelleborg.

In an early interview Enquist said:

'We wanted to give the film a factual, dry tone, in which the sound layer is extremely important. A recurring voice-over keeps asking questions, giving us facts that sometimes coincide with the image, and sometimes collide with it' (Edberg 1969). While Enquist had used character compression to synthesise the existing and fictional people in his book, the juxtaposition in the film is between the images and sound - something that Bergenstråhle would continue to work on in his filmmaking. In his review of the film, Hans Schiller recalls one of the most distinct scenes:

On screen we see the burning torches at the protest meetings against the extradition, and on the sound track we hear a scene from a few years earlier, of Jews applying for and being refused permits to enter Sweden. 

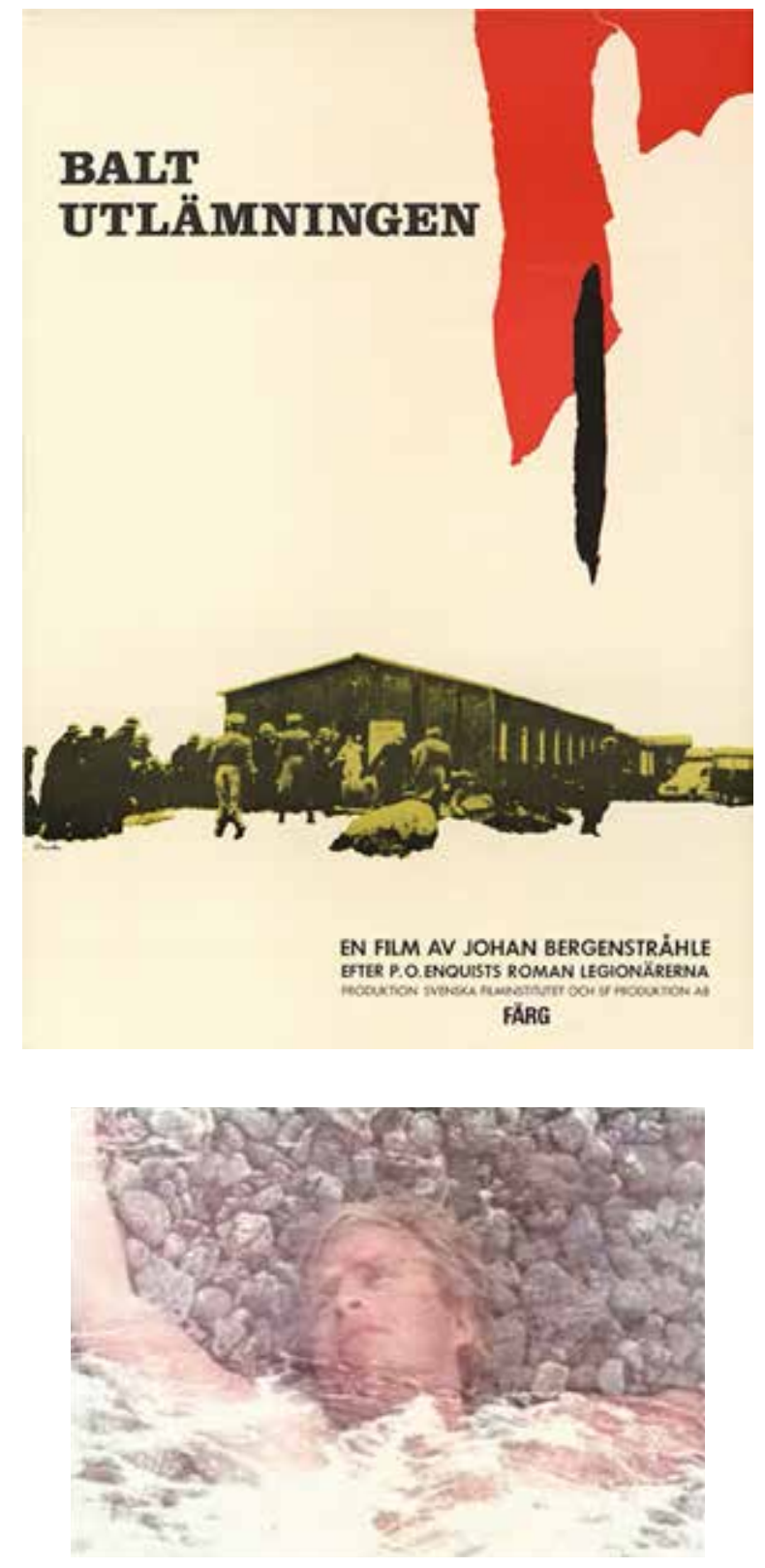

FIGURE 2. The poster for Johan Bergenstråhle's

A Baltic Tragedy (Baltutlämningen, Sweden, 1970). Designed by Ragnar Sandgren.

FIGURE 3. Johan Bergenstråhle, A Baltic Tragedy (Baltutlämningen, Sweden, 1970). Dream sequence of one of the Baltic soldiers illustrated by double exposure images. 
The parallel provides two aspects. The first being that the refusal of the government to carry out the extradition to the Soviet Union could be perceived as furthering the position of neutrality; and the second being that it was easier for Swedish public opinion to protest after the danger and fear of Nazi Germany was over, and the Balts could be the object of sympathy instead of the Jews. (Schiller 1970b)

According to Schiller, this makes the expression of the film ambiguous in regard to the historical events. Another problematic sequence is the one in which a Baltic soldier sticks himself in the eye with a pencil in order not to be extradited. Having done so, the film immediately cuts to the soldier's dream sequence, where he - according to the voice-over - sees a Latvian nurse beckoning him to come home. As we hear the traditional Neapolitan Song of Lucia (St. Lucy), as it is sung in Swedish at the Feast of Saint Lucy every December, we see the images of war, ruins, fire and concentration camps showing death and destruction. (Figure 5) This episode is based on a true story told by Edvins Alksnis, who survived such a suicide attempt. However, he protested 'against the way in which his suicide attempt in the film is accompanied by images of murdered people in the Baltics'. The sacred account of an individual's history seemed to be violated by painting with a broad allegorical brush, so that the images of the extermination of the Jews become the narrative context. Alksnis asserts, "I have never killed anyone, either at the front or behind the lines', and therefore it is unfair that 'his person has been used for a story that does not correspond with the truth' (Julin 1970). As we saw with Enquist's account of the Baltic soldiers, their connection to the German Wehrmacht was debatable and overall an infected issue. Alksnis is reported to have protested against this contextualisation, saying that 'I get upset when I see that I would have dreamed of the camps afterwards - that I would have felt guilty [about being in the army]. That's wrong. That never happened' (Anonymous 1970).

The film had its Swedish premiere on 30 September 1970, but it totally flopped at the box office - a fact we will return to later. The critics, on the other hand, were mostly positive, discussing not only the film but also the historical course of events and the film's relation to Enquist's novel. Jurgen Schildt in Aftonbladet described the film as 'a cold and shaking testimony' and wrote about 'the scenes in this series of taboos, faces and statements that, with coolness of contrast and recollection, create a rift in the secure people-friendly world' (Schildt 1970). Hanserik Hjertén wrote that 'there is something problematic in the way Bergenstråhle has made the film version, in the thinning of the key dimensions of the book', and yet
it tells about something unbeliev- able that happened in the Swed- ish idyll, and about ourselves and our conscience in the great horrible game with people. I still think Bergenstråhle has rescued his film with an impact that will reach a broader audience than the book. (Hjertén 1970)

The most emphatically negative review was written by Jonas Sima who was annoyed by Bergenstråhle's form of expression and criticised it as 'wound-fetishism that smears the document and directs the discussion of the events in an undesirably impassioned direction that does not match the generally balanced tone of the movie and the book' (Sima 1970). (Figure 6) Bergenstråhle would later criticise Sima for the unfavourable review, which according to Bergenstråhle spoiled the film's chances at the box office. In addition to this, the Greek immigrant writer Theodor Kallifatides also attacked Sima, writing:

Sima's review also expresses another common misconception, namely that 


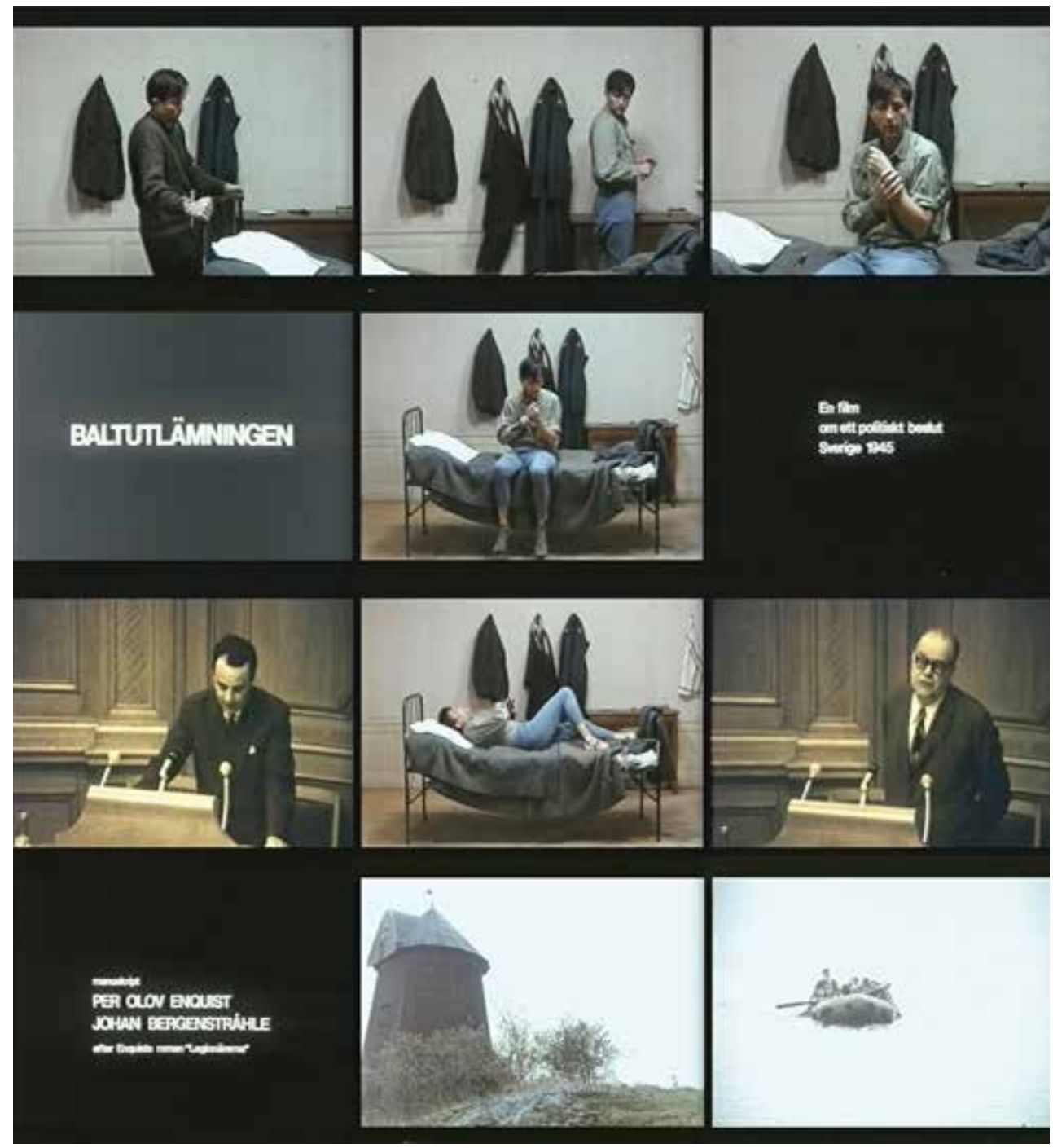

FIGURE 4. Johan Bergenstråhle, A Baltic Tragedy (Baltutlämningen, Sweden, 1970).

The opening of the film. A montage of the suicide, title and intertitles, parliamentary debate, film credits and the arrival of the soldiers on the island of Gotland. 
objectivity and impartiality require emotional scarceness. This is false moralism combined with overconfidence in the ability to be objective. [---] A dimension of the film has not been examined enough - something I would call 'dialectic objectivity'. It consists of the artist not only describing a situation but also discussing the narrative and the underlying values with his audience without claiming clear objectivity. In that way, the common reality becomes the subject of dialogue. (Kallifatides 1970)

Bergenstråhle and Kallifatides would later collaborate on Kallifatides' own autobiographical story, which was titled My Name Is Stelios (Jag heter Stelios, Sweden, 1972). In a recent interview with Kallifatides, he recalls that Bergenstråhle 'was more interested in provoking' and that he was 'just like the period, temperamental and politically committed' (Aretakis 2017). The point is that while Bergenstråhle was provocative towards his audiences, using juxtapositions and dialectics in order to prompt them to reflect, Enquist's book does all that in a far subtler manner, while always keeping the question of trauma at hand. The film is actively unsettling to its viewers, while the book leaves the unnerving features to the readers to discover.

The dialectic perspective proposed by Kallifatides is supported by Bergenstråhle's own statements about the film. While still filming, Bergenstråhle stated in an interview, 'there is a dialectic in the book that we want to transfer to film' (Edberg 1969). However, the omission of the investigator, which had proved so vital for the I-witness component of the book is an important aspect of the film. Bergenstråhle explains his focus: "I have left out the investigator of the book and gotten a hold of the parts that together tell a linear story, by moving the action forward' (Stawonius 1969). There is a sense here that identifying with an investigator would come between the spectator and the spectacle. The aim is for the audience to have strong emotions about the individual scenes and, as Bergenstråhle states, that 'these scenes result in people asking what they knew about the extradition: What did I really feel? And why?' (Frankl 1970). It is clear that the I-witness account was at the forefront of the filmmaking, and that it aimed to create witnesses to the trauma. Bergenstrăhle wanted his audiences to get involved and to 'react emotionally' (Frankl 1970).

As already mentioned, the film was a failure at the box office, seen by no more than 75,000 people in the cinemas (Bergqvist 1970, Vinberg 1970). There were many explanations about why the film did not find its audience. Björn Vinberg discusses several possible reasons for the failure, such as lack of film stars and a political theme, but also proposes that 'the film is about a sensitive chapter in Swedish history. Our blue-eyed conscience is (with or without cause) a bit sick. We do not want to be worried again' (Vinberg 1970). We believe that Vinberg's observation supports our view that the film aimed to create witnesses to the trauma through inducing a guilt complex in the audience. This assignment of guilt was underlined in a televised debate organised at the time of the premiere. In it, the politicians who were involved in the decision to extradite the Balts together with diaspora historians were interviewed about the objectivity of the film. Although very few of the television viewers had actually seen the film, the question of guilt was a hot topic.

There is no question that more witnesses were created when the film was broadcast on national television seven years later in January 1978. However, we believe that the political climate of the period had changed by this time and that the left-wing Marxism that had coated the cinematic style of the film, as well as the narrative form of the book, had mostly evaporated (Östberg 2008: 347-348). We can see this in the changing views of two specific reviews, which were published in connection with the film's broadcast on television. In one of them, Hans Schiller argues that a clarifying statement from the 

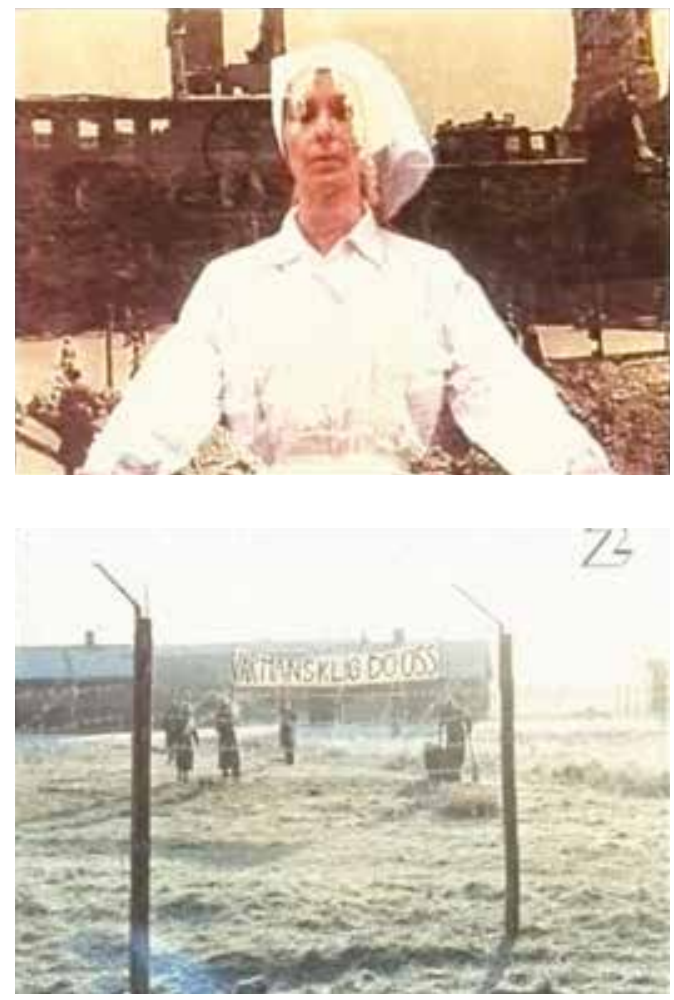

Johan Bergenstråhle, A Baltic Tragedy (Baltutlämningen, Sweden, 1970).

FIGURE 5. The narrator says: 'A Latvian nurse in a Russian uniform stood by his sick bed asking him to come home...'

FIGURE 6. A protest inside the incarceration camp. The sign reads 'Be Human, Kill Us'. 
filmmaker is missing, and, more importantly, he deemed Bergenstråhle's documentary method to be immoral (Schiller 1978). The emotionally provocative style of filmmaking was deemed too argumentative and propagandistic. Lasse Bergström, in his second review of the film, refers to Sima's critique highlighted above, pointing out, in a rather negative tone, that the film will hopefully find its proper format on the television screen (Bergström 1978). While there is no audience data for the television broadcasts, we assert that more people saw the film on television than on the big screen.

\section{CONCLUSION}

In conclusion, we would like to reiterate that while Enquist's novel is still gaining currency as a book that disrupted the foundation of contemporary Swedish society, the film has now been forgotten. The extradition of the Baltic soldiers is still recurring as a collective national trauma, as an example of what happens when a society fails to act according to its moral principles and humanistic ideals. This is despite the fact that many consider the decision to extradite to be a politically correct one. In order to maintain neutrality, the politicians had to act even-handedly in order to ensure a balanced handling of foreign affairs. This meant bending to the Soviets, as well as to the other victors of World War II. What we have tried to do in this article is to conflate three different time periods, in order to track the making of a national trauma. The first event is the actual extradition, which was hastily forgotten, although it was a dramatic event, especially for the various political divisions, as well as different national and diasporic groups. What is being questioned at this time is the idea of post-war Sweden and how the nation should have reacted in the face of outside pressure. The second period is the late 1960s, when Enquist resuscitated the event as a political act in order to provoke the same question of bowing to pressure, while also probing the ideas of national cohesion. We have argued that Enquist's book managed to elevate the historical event to a collective trauma, and that Bergenstråhle's film exacerbates this trauma by creating eyewitnesses to the event. The twist to the tale is that the film's stylistic and argumentative expression faded in the aftermath of the May revolt and Prague invasion of 1968. Creating witnesses through politically engaged spectatorship would die before the decade was over. This is evident in the demise of Bergenstråhle's career. The same year as A Baltic Tragedy was broadcast on television, Stig Björkman wrote an essay on Bergenstråhle, pointing out that there can be no objectivity regarding this film. Björkman emphasises that the scenes from the camp 'cannot help but affect the viewer' and although 'Bergenstråhle strives for objectivity through this versatile illumination, the results are predictable. No argument in the real world can have the same impact as the bloody and violent images that appeal directly to our compassion' (Björkman 1978: 122-123). Björkman continues: 'Even if all views are considered, the form of $A$ Baltic Tragedy invokes engagement without responsibility' (Björkman 1978: 123). The film has now been relegated to the history books. 


\section{REFERENCES}

Anonymous 1970. 'Huvudpersonen i Stockholm starkt kritisk'. - Expressen, 2 October. Aretakis, Leonidas 2017. 'In kommer Stelios från den svenska filmhistorien'. - FLM, 5 October. http://flm.nu/2017/10/in-kommer-stelios-franden-svenska-filmhistorien/ (8 July 2018).

Ashuri, Tamar 2010. 'I Witness: Re-presenting Trauma in and by Cinema'. - The Communication Review 13, 3, 171-192.

Bergqvist, Kerstin 1970. 'Publiken sviker "Baltutlämningen” och regissören făr inget jobb'. - Aftonbladet, 31 October.

Bergström, Lasse 1970. 'Tragedin att vara människa'. Expressen, 7 July.

Bergström, Lasse 1978. 'Baltutlämningen'. -

Expressen, 13 January.

Björkman, Stig 1978. Nya bilder och dagsljus. Tio svenska regissörsporträtt. Stockholm: PAN/Norstedt. Brown, Andrew 2016. 'PO Enquist: "An Upbringing Like Mine Marks You Like a Branding Iron”'. - The Guardian, 30 July. https://www.theguardian.com/books/2016/ jul/30/upbringing-like-mine-marks-you-like-brandingiron-per-olov-enquist-interview (8 July 2018). Buelens, Gert; Durrant, Sam; Eaglestone, Robert 2014. 'Introduction'. - Gert Buelens, Sam Durrant, Robert Eaglestone (eds.), The Future of Trauma Theory: Contemporary Literary and Cultural Criticism. London: Routledge, 1-8.

Cato, Åke 1970. 'Protest mot “Baltutlämningen”'. -

Expressen, 7 July.

Eaglestone, Robert 2014. "Knowledge, "Afterwardness" and the Future of Trauma Theory'. - Gert Buelens, Sam Durrant, Robert Eaglestone (eds.), The Future of Trauma Theory: Contemporary Literary and Cultural Criticism. London: Routledge, 11-21.

Edberg, Ulla-Britt 1969. 'Fullständig ärlig redovisning kräver inspelning i fyra plan'. - Svenska Dagbladet, 12 September.

Ekholm, Curt 1984. Balt- och tyskutlämningen

1945-1946. PhD thesis. Uppsala universitet.

Enquist, Per Olov 1966. 'Häng slöddret!' - Expressen, 5 October.

Enquist, Per Olov [1968] 2018. Legionärerna. En roman om baltutlämningen. Stockholm: Norstedt. Enquist, Per Olov 1970a. 'Jag skulle ha skrivit en likadan bok i dag'. - Expressen, 16 August.

Enquist, Per Olov 1970b. 'Insinuationer - men inga belägg'. - Expressen, 30 September.

Enquist, Per Olov 1973. The Legionnaires: A Documentary Novel. Trans. Alan Blair. New York: Delacorte Press. Erll, Astrid 2017. 'Travelling Memory in European Film:

Towards a Morphology of Mnemonic Relatedness'. Image [\&] Narrative 18, 1, 5-19.

Frankl, Elisabeth 1970. 'Vårt engagemang räcker bara för orättvisor på andra sidan jorden'. - Expressen, 27 September.

Freivalds, Osvalds 1968. De internerade balternas tragedi i Sverige år 1945-1946. Stockholm: Lettiska förening Daugavas Vanagi.

Freivalds, Osvalds 1971. Sverige och de baltiska staternas ockupation. Stockholm: Lettiska Nationella Fonden.

Gustafsson, Lars 1969. 'Är författaren onödig?' -

Expressen, 28 October.

Gustafsson, Sture 1968. 'Vårt transportabla

samvete'. - Vår kyrka 48, 8-9.

Hiden, John; Made, Vahur; Smith, David J. (eds.) 2008.

The Baltic Question During the Cold War. London: Routledge.

Hjertén, Hanserik 1970. 'Upplysande men förenklat'. Dagens Nyheter, 1 October.

Johansson, Anders 2008. Nonfiction. Gothenburg: Glänta Produktion.

Julin, Gösta 1970. 'Vädjan till Palme. Häv hemligstämpeln om baltutlämningen'. - Dagens Nyheter, 2 October.
Kallifatides, Theodor 1970. 'Sima önskar inget samtal'. - Expressen, 7 October.

Kaplan, Ann E. 2001. 'Melodrama, Cinema and Trauma'. - Screen 42, 2, 201-205.

Kaplan, Ann E.; Wang, Ban 2004. 'Introduction: From Traumatic Paralysis to the Force Field of Modernity'. Ann E. Kaplan, Ban Wang (eds.), Trauma and Cinema: Cross-Cultural Explorations. Hong Kong: Hong Kong University Press, 1-22.

Küng, Andres 1970. 'Regeringen och balterna'. Expressen, 6 October.

Lagercrantz, Olof 1968. 'Enquists bok om baltutlämningen. Ett stycke samtidshistorisk konfliktforskning'. - Dagens Nyheter, 2 September. Lagerlöf, Karl Erik 1968. 'Vid roten av en svensk samvetsfråga'. - Göteborgs Handels och Sjöfartstidning, 2 September.

Laks, Harri 1969. 'Baltisk syn på Legionärerna'. -

Göteborgs Handels- och Sjöfartstidning, 25 March. Landsmanis, Arturs 1970a. De misstolkade legionärerna. Ett baltiskt debattinlägg. Stockholm: Lettiska Nationella Fonden.

Landsmanis, Arturs 1970b. 'En man på flykt knackar på.... - Expressen, 30 September.

Liffner, Axel 1968. 'Legionärerna. En roman om baltutlämningen'. - Aftonbladet, 2 September.

Linder, Erik Hjalmar 1968. 'Baltutlämningens roman'. Göteborgs-Posten, 2 September.

Matheron, François 1997. 'Introduction'. - Louis

Althusser, The Spectre of Hegel: Early Writings. Ed.

François Matheron, trans. G. M. Goshgarian. London,

New York: Verso, 1-13.

Maurina, Zenta 1968. Befrielsens år. Svenska dagböcker 1951-1958. Trans. Brita Edfelt. Stockholm:

P. A. Norstedt \& Söners Förlag.

Mazierska, Ewa 2011. European Cinema and Intertextuality: History, Memory and Politics. Basingstoke: Palgrave Macmillan.

Mazierska, Ewa 2014. 'The Meaning of History and the Use of Translation in News from Ideological Antiquity Marx/Eisenstein/The Capital (Video 2008) by Alexander Kluge'. - Ewa Mazierska, Lars Kristensen (eds.), Marx at the Movies: Revisiting History, Theory and Practice.

Basingstoke: Palgrave MacMillan, 244-266.

Narine, Neil 2010. 'Global Trauma and Narrative Cinema'. - Theory, Culture \& Society 27, 4, 119-145. Nilsson, Sven; Yrild, Rolf 1972. 'Per Olov Enquist: Legionärerna (1968)'. - Sven Nilsson, Rolf Yrild (eds.), Svensk litteratur i kritik och debatt 1957-1970. Stockholm: Bokförlaget Prisma, 211.

Östberg, Kjell 2008. "Sweden and the Long "1969": Break of Continuity'. - Scandinavian Journal of History 33, 4, 339-352.

Schildt, Jurgen 1970. 'Baltutlämningen - ett kallt och skakande vittnesbörd'. - Aftonbladet, 1 October. Schiller, Hans 1970a. 'En mosaik av småbitar'. Svenska Dagbladet, 7 July.

Schiller, Hans 1970b. 'Vår brist på förståelse'. Svenska Dagbladet, 1 October.

Schiller, Hans 1978. 'Baltutlämningen brännbar film... men saknar ett ställningstagande'. - Svenska

Dagbladet, 14 January.

Seidensticker, Edward G. 1972. 'Introduction'. -

Yasunari Kawabata, The Master of Go. Trans. Edward G. Seidensticker. New York: Alfred A. Knoff, v-viii. Seierstad, Åsne 2018. 'Ett svenskt trauma'. - P. O. Enquist, Legionärerna. Stockholm: Norstedt, 7-11. Sima, Jonas 1970. 'Utmärkt filmsort - för TV'. Expressen, 1 October.

Sjöström, H. 1969. 'Politisk roman'. - Vår kyrka 3, 17. Stawonius, Betty 1969. 'Baltutlämningen på film. En dokumentär skildring'. - Dagens Nyheter,

4 November.

Svedgård, Lars 1970. 'Så gick det till när balterna utlämnades'. - Expressen, 30 June.

Tansley, Laura; Maftei, Micaela 2015. 'Pathways to 
Determining Form'. - Laura Tansley, Micaela Maftei (eds.), Writing Creative Non-Fiction: Determining the Form. Canterbury: Gylphi, 1-18.

Thurah, Thomas 2002. Så hvad er et menneske. Tre kapitaler om P.O. Enquist, Peer Hultberg og Jan Kjærstad. København: Samleren.

Torchin, Leshu 2006. 'Ravished Armenia: Visual

Media, Humanitarian Advocacy, and the Formation of Witnessing Publics'. - American Anthropologist 108, 1 , 214-220

Torchin, Leshu 2012. Creating the Witness:

Documenting Genocide on Film, Video, and the Internet.

Minneapolis, London: University of Minnesota Press.

Uisk, Ahto 1968. 'Baltutlämningen en tagg i det svenska samvetet'. - Arbetaren, 2 September.

Unger, Gunnar 1968. 'Sovjetunionen äreräddad'. -

Svenska Dagbladet, 2 September.

Vinberg, Björn 1970. 'SF har inte råd med Bergenstråhle'. - Aftonbladet, 21 November.

Walker, Janet 2001. 'Trauma Cinema: False Memories and True Experience'. - Screen 42, 2, 211-216.

Walker, Janet 2005. Trauma Cinema: Documenting Incest and the Holocaust. Berkeley: University of California Press.

Zetterström, Margareta 1970. “'Det finns ingen helgonlik objektivitet”. En studie i Per Olov Enquists Legionärerna'. - Bonniers Litterära Magasin 39, 524-532. 